\title{
THE IMPACT OF EXCHANGE RATE FLUCTUATIONS AND MONEY SUPPLY ON INFLATION IN SIERRA LEONE (1986-2019)
}

\author{
Mohamed Ibrahim Justice Ganawah \\ Lecturer at the Department of Economics and Commerce Fourah bay College, University of Sierra Leone \\ DOI: 10.46609/IJSSER.2021.v06i02.004 URL: https://doi.org/10.46609/IJSSER.2021.v06i02.004
}

\begin{abstract}
This paper aims at providing quantitative analysis of the impact of money Supply and exchange rate fluctuations on inflation in Sierra Leone. The paper utilizes secondary data that were obtained from the International Financial Statistics (IFS), of all variables investigated in the model. The sample covers quarterly data from 1986:01 to 2019:04. The model was estimated using Vector Error Correction Mechanism (VECM).

The empirical results confirm that in the long run, money supply and exchange rate have significant inverse effects on inflationary pressure, while real output growth and foreign price changes have direct effects on inflationary pressure. The possible justification for the inverse effect of money supply on price level is that inflation may not be due to aggregate demand pressure but rather due to hiccups in the supply chain of goods both from the domestic and foreign supply outlets. Empirical deductions also signify the presence of significant feedback from the long run to short run disequilibrium. However, there exists a causal linkage between inflation, money supply and exchange rate in Sierra Leone.
\end{abstract}

Keyword: Money supply, Exchange rate, Inflation, Real output

\section{INTRODUCTION}

The economy of Sierra Leone economy, like most developing economies, started experiencing economic problems in the 1970s. The problems that were notable in that era were exchange rate fluctuations, inflation, chronic balance of payments deficits and declining output which lead to excessive demand and fiscal instability, associated monetary instability and the absence of organized markets for securities and equities.

Sierra Leone operates an open economy and this has made her to involve in international trace financed, with its rich mineral resources and agricultural exports (mainly coffee and cocoa). These commodities have provided much of the foreign exchange earnings before the outbreak of 


\section{International Journal of Social Science and Economic Research}

ISSN: $2455-8834$

Volume:06, Issue:02 "February 2021"

the rebel war in the 1991; they have not been meaningfully exploited for economic growth and development to the benefit of all. The country stilled one of the poorest in the world with the majority of the populace living in abject poverty.

Exchange rate, money supply and prices are interrelated and affect each other. In the pursuit of non-inflationary policies, authorities target all three nominal variables in a consistent manner. However, the question is whether an announced commitment to target particular variable (rather than others) would be more binding and therefore more credible. Although it is difficult to be unequivocal on this issue, an announced fixing of the nominal exchange rate may be preferable in targeting either inflation or money supply.

Conceptualizing the linkages between growth in money supply and the general price level is relatively straightforward-increases in money supply lead to increase in prices. Price level changes results mainly from exchange rate devaluation. This is predicted on the assumption that the induced increases in the prices of imported inputs and final goods, following a devaluation of the local currency are passed on to the local consumer.

The rate of increase in the general price level and the exchange rate regime operation are also closely related, for instance, when a crawling peg exchange rate adopted in the economy, the implications are that it may lose a nominal anchor which could lead to inflation. Accordingly, the rate of inflation could become uncontrollable. This is because the exchange rate and money supply are indices to the price level. Exchange rate changes the rate of increase in the price level affected each other to produce and inflation-devaluation spiral or a vicious circle in flexible exchange regimes or pass-through effects from the exchange rate changes and the foreign price level. These effects may worsen the domestic inflation rate.

According to Keren and Pack (1980), the strength of the pass-through effects depends on the price elasticities. The loss of a nominal anchor could imply that shocks to the rate of inflation will have lasting effects, pushing the rate of inflation to a higher level and depreciating the exchange rate. In this case, exchange rate movements, money supply growth and changes in the rate of inflation drive each other. The Sierra Leone experience shows that for many years the exchange rate and the domestic price level have been unstable. Accelerating money supply growth, fiscal deficit and foreign exchange squeezed compounded the problem of inflation and exchange rate depreciation.

Governments of developing countries including Sierra Leone have made efforts to achieve a steady exchange rate and slow growth in the money supply and general price level, but from research, it has been proven that there have been continuous fluctuations in these macroeconomic variables in the past four decades. It is also crystal clear that Gross Domestic Product (GDP) has 


\section{International Journal of Social Science and Economic Research}

ISSN: $2455-8834$

Volume:06, Issue:02 "February 2021"

been falling, while unemployment rate increasing. Also, inflation rate has been increasing, exchange rate and balance of payments, fluctuations have been worsening. The balance of payment crisis resulted among other things, a growing parallel market for foreign currency, which has been very difficult to control. Whilst the consequences onthe economy have been severe.

Few studies have been conducted to explain the fluctuation of exchange rate and money supply on the general price level in Sierra Leone. Few have linked the exchange rate policy and monetary policy. Most studies have concentrated on explaining the domestics' rate of inflation, where the nominal exchange rate enters as one of the explanatory variables (Canectti and Greene, 1991; Killick and Mwega, 1989; Mwega, 1990; Ndung'u, 1993 1996). Others have estimated a money demand equation where the nominal exchange rate enters as one of the explanatory variables (Adam, 1992). Only two of these studies attempts to establish a statistical relationship between money and the exchange rate. For example, in Canectti and Greene (1991) and Ndung'u (1995), money supply growth, inflation and exchange rate (among other variables) are analyzed in a vector autoregressive model. The authors find that money supply growth drives nominal exchange rate changes with no feedback effects.

In assessing the effect of exchange rate fluctuations and the growth in money supply on the general price level, an answer would be needed for the question below; are there link between nominal money supply and the nominal exchange rate? In the long run, De Grauwe (1994) argues that the correlation between money supply and the nominal exchange rate is relatively strong but tends to be lost in the short run. We would expect this relationship to be stronger in periods of nominal exchange rate flexibility. And finally, how do fluctuations in exchange rate and the growth in money supply affect the general price level in Sierra Leone is worthy of research at this point in time.

This paper seeks to examine the effects of exchange rate fluctuations and money supply on the general price level. Specifically, the paper examines whether increase in the price level drive, changes in the exchange rate or the growth in money supply.

\section{LITERATURE REVIEW}

\subsection{THEORETICAL LITERATURE}

Literature on recent theories of inflation that have emerged in the past few years emphasised the role played by political stability, policy credibility and the reputation of the government and the political cycles in determining or explaining inflation. According to Selialia (1995), this literature on inflation has come to be known as the political economy approach to macroeconomic policy. These recent theories of inflation have shifted attention away from 


\section{International Journal of Social Science and Economic Research}

ISSN: $2455-8834$

Volume:06, Issue:02 "February 2021"

traditional direct economic causes of inflation, such as money creation, towards political and institutional determinants of inflationary pressures. However, these theories have been criticised as they are theoretical and put emphasis almost exclusively on industrial countries. Structural factors are also believed to influence the rate of inflation. Examples of these are the weather conditions, and protective industrial and trading policies of the government. It can be argued that government protects infant industries from intra currency area trade and regulates domestic marketing of agricultural products by quantitative import restrictions through import permits or licensing.

These policies are believed to have created monopolistic and oligopolistic structures of firms, which usually set their prices well above border prices. The general feeling is that these policies may be highly inflationary as prices of some of the controlled items may rise quickly.

Weather conditions, crop failures or drought are some of the structural factors that are also believed to have a direct impact on the inflation rate given that food items carry the biggest weight in the computation of the Consumer Price Index (CPI). During good weather (rainy agricultural year), prices in general, are expected to fall in the future and vice versa. Several studies have been conducted examining the impact of exchange rate and money supply on inflation. The impact of exchange rate movements on inflation and growth has been widely discussed and numerous channels through which the effects of currency fluctuations are transmitted onto the domestic price level and output have been identified in the literature.

\subsubsection{IMPACT OF EXCHANGE RATE ON INFLATION}

Exchange rate movements can impact on domestic prices through direct and indirect channels, via their effect on aggregate supply and demand. The direct channel is due to operation of law of one price based on purchasing power parity theory (PPP). It is postulated that exchange rate between two currencies is determined by relative movements in the price levels in the two countries. PPP states that price levels between two countries are equal when expressed in the same currency at any period of time. Therefore, if PPP holds, exchange rate fluctuations translate into proportional movements in the domestic price level; i.e. pass-through is equal to one. In a small open economy (an international price taker), a depreciation of the domestic currency will result in higher import prices (both for finished goods and intermediate inputs), which will ultimately be transmitted to higher domestic prices (See Hyder and Shah, 2004).

Exchange rate variations can also affect domestic prices through its indirect effect on aggregate demand. Depreciation of the domestic exchange rate reduces the foreign price of domestic goods and services, and thereby increases foreign demand, resulting to an increase in net exports and hence aggregate demand and real output. The increase in domestic demand and real income may 


\section{International Journal of Social Science and Economic Research}

ISSN: $2455-8834$

Volume:06, Issue:02 "February 2021"

bid up input prices and hence causing workers to agitate for higher wages to maintain a real wage. The nominal wage increase may result to further price increases (See Hyder and Shah, 2004). Furthermore, depreciation may increase the domestic price of imported goods and services and thereby lead to expenditure switching in favour of domestic goods and services, which will increase their demands and raising domestic prices.

\subsubsection{IMPACT OF EXCHANGE RATE ON OUTPUT}

The literature on the impact of exchange rate fluctuations on output has produced mixed results. The traditional views such as the elasticity, absorption and the Keynesian approaches assert that devaluation have positive effect on output. The elasticity approach states that devaluation will improve the trade balance and hence output

growth, assuming the Marshall-Lerner condition holds. In other words, if the sum of the price elasticity of exports and imports exceeds unity, the devaluation will lead to an improvement in the current account. Hence, devaluations lead to an increase in aggregate demand. In this approach, devaluation will increase the domestic price of foreign imports and reduce the foreign price of domestic exports. This will result to a decrease in import and an increase in exports, thereby increasing net export, trade balance output.

\subsection{EMPIRICAL LITERATURE}

Numerous researchers have studied the impact of exchange rate fluctuations and money supply on inflation and have produced mix results, based on methodological or geographical differences as well as the type of data used. In terms of methodology, Copelman and Werner (1996), by using a VAR model for Mexico with five variables - output, the real exchange rate, rate of depreciation of the nominal exchange rate, the real interest rate, and a measure for real money balances-showed that declines in output are observed after a devaluation. During the same period, Kamin (1996) showed that the level of the real exchange rate was a primary determinant of the rate of inflation in Mexico during the 1980s and 1990. In a related study, Kamin and Roger (2000) examined the impact of depreciation on output and inflation in Mexico employing VAR model with four variables; real exchange rate, output, price index and US interest rate using quarterly data for the period 1981-1995. The result revealed depreciation shock leads to reduction in output and an increase in inflation. Sheeley (1986) also found that devaluations have a negative impact on output for Latin American countries, while the study by Calva, Reinhart and Vegh (1994) identified correlation between inflation and the real exchange rate in Brazil, Chile and Colombia.

Using pooled time-series/cross-country analysis on the other hand, Edwards (1989) found that devaluations reduce output in developing countries in where the real GDP is explained by the 


\section{International Journal of Social Science and Economic Research}

ISSN: $2455-8834$

Volume:06, Issue:02 "February 2021"

real exchange rate, government spending, term of trade, and money growth. Morley (1992) also regressed capacity utilization to the real exchange rate, measures of fiscal and monetary policy, and term of trade, export growth and import growth in a pooled time-series/cross $M$ country analysis and found that real devaluation tended to reduce output and it took at least two years for the full effects to show.

Using nonlinear three-stage least squares estimation, Domac (1997), based on Turkish data for 1960-90, showed that unanticipated devaluations have positive effects on output but anticipated devaluations do not exert any significant effect on output. In a similar analysis, Mills and Pentecost (2000) used a conditional error correction model for four European Accession countries: Hungary, Poland, Slovakia, and the Czech Republic. They found that real exchange rate depreciation had positive effects in Poland, no significant effect in Hungary and the Czech Republic, and negative effects in Slovakia. Grigorian, et al (2004) analyzes the dynamic effects of the exchange rate on prices in Armenia. By studying three inter-related markets (foreign exchange, money and labour), their estimation shows higher responsiveness of inflation to the exchange rate rather than to the other determinants (money supply and nominal wages). Their study revealed a negative correlation between inflation and exchange rate both in the short- and long-run.

Chhibber et al (1989) developed an economic model that considered both monetary and structural factors as the causes of the increases in the general price level (inflation) in Zimbabwe. They concluded that growth in money supply and exchange rate are the chief determining factors in explaining the increases in the general price in Zimbabwe. A similar study carried out in Ghana by Chhibber and Shafik (1990), covering the period 1965-1988, suggested that growth in money supply is one key variable explaining upward movements in the general price level. The authors however, maintain that the official exchange rate did not cause significant effects on the

increases in the general level. They nevertheless observed a direct relationship between the parallel exchange rate and the general price level.

Sowa and Kwakye (1991) determined that trends and controls of inflation (increases the general price level) in Ghana. They like-wise used an econometric model to resolve the relative effects of monetary and structural factorson the general price level.

One of their findings was that monetary expansion exerted some positive influence on the price level. According to them, the exchange rate does not impact directly on the movement in prices echoing one of the deductions of Chhibber and Shafik (1990).

In Uganda, Elbadawi's (1990) research revealed that rapid monetary expansion and precipitous depreciation of the parallel exchange rate were the principal determinants of increases in the 


\section{International Journal of Social Science and Economic Research}

ISSN: $2455-8834$

Volume:06, Issue:02 "February 2021"

general price level during 1988/89. He compared the exchange rate does not increase the price level. This is consistent with the findings of Chhibber and Shafik (1990) and Sowa and Kwakye (1991) using date from Ghana.

In contrast, Tegene (1991) investigated the role of domestic money supply in the research for causes of inflation in six African countries using a different methodology. He carried out the Grange and Pierce causality test rather than the traditional econometric techniques and demonstrated a unidirectional causality from monetary growth to increase in the general price level. This methodology was also used by Cannetti and Greene (1991) to evaluate the relative contribution of exchange rate movements and monetary growth to price inflation in ten African countries during 1978 to 1987 . The main conclusion was that exchange rate movements and monetary growth explain trends in the increases in the general price level in the countries studied. The bivariate and trivariate Granger tests show that the exchange rate has significant causal influence on the increases in the general price level in Sierra Leone, Tanzania, and Zaire. With regards to the monetary supply role, the statistical tests identified causation from money to prices in Gambia, Sierra Leone and Uganda. For Nigeria and Zambia, the various test performed could not identify any significant causal relationship between money, inflation and exchange rate.

In earlier Studies Pinto (1987) maintained that monetization of the foreign exchange earnings from crude oil exports expanded the growth in narrow money (M1) and that this was the most important single factor which explains that movements in the general price level in the 1970s to early 1980 s in Nigeria.

The empirical literature has also produced conflicting results based on geographical classification. For instance, Bahmani- Oskooeeet al. (2002) investigated the effect of currency depreciation on output in Asian countries. He found that in many Asian country's depreciation is contractionary. Also, Bahmani-Oskooee and Rhee (1997) using Korean quarterly data over the period 1971-1974 applied Johansen's cointegration and error-correction technique. Their errorcorrection model confirmed that there exists a long-run relationship between output, money and the real exchange rate variables. They concluded that real depreciations were expansionary in the long-run and the most important expansionary impact of real depreciations appeared with a lag of three quarters. Christopoluos (2004) on the other hand, investigated the effect of currency devaluation on output expansion in 11 Asian countries over the period 1968-1999. He found that, in the long run, the depreciation exerts a negative impact on output growth for five countries while for three countries depreciation improves growth prospects. De Silva and Zhu, (2004) considered the case of Sri Lanka and applied the VAR technique. Using quarterly data over the period 1976-1998, they concluded that devaluation improved the trade balance but had a contractionary impact on the Sri Lankan economy. 


\section{International Journal of Social Science and Economic Research}

ISSN: $2455-8834$

Volume:06, Issue:02 "February 2021"

Gylfason and Risager (1984) studied the effects of devaluation for 8 developing and 7 developed countries. They concluded that devaluation was expansionary in developed countries and contractionary in developing countries. Solimano (1986) constructed a macroeconomic model for Chile and concluded that devaluation was

contractionary in the short to medium run. In a related development, the study by Loungani and Swagel (2001) using a panel of 53 developing countries: African countries - 16, Asian - 11, South American - 19, and

Mediterranean -7 revealed that in developing countries with the floating exchange rate, the impact of exchange rate depreciation on the price changes is positive and statistically significant. The same results are obtained in the studies estimating the relationship between the exchange rate and inflation separately for individual developing countries.

In a separate study on the inflation dynamics in the WAMZ Member States, Kitcher, et al (2007) examined the main determinants of inflation in The Gambia using single equation errorcorrection model. Their findings are that inflation is driven mainly by inflation inertia and external factors in the short run and mainly by monetary factors in the long run. Real output, however, appear not to have any significant effect on inflation in the Gambia. In a related study conducted for Ghana, Abradu-Otoo and Donyina-Ameyaw (2007) find that the main determinants of prices in the long run are the exchange rate, base money, retail prices of petroleum products and the general level of economic activity. Concerning the impact of inflation and economic growth in Ghana over the period 1987(3)-2007(4), Adenutsi reveals that inflation has a marginal short-run positive impact on growth but this impact turns negative in the long run. Furthermore, Onwioduokitet al (2007) establish that the key factors influencing inflation in Guinea are inflation inertia, exchange rate, fiscal deficit and output. Essien, Onwioduokitet al (2007) find that the key factors influencing inflation in Nigeria are past levels of inflation, monetary aggregates, fiscal deficit and exchange rate. Using vector error-correction model, Essien, Adamgbe and Sesay (2007) identify key determinants of inflation in Sierra Leone as inflation inertia, money supply and exchange rate.

Despite the plethora of empirical literature on the impact of exchange rate fluctuations and money supply on inflation, there does not seem to be any study with exclusive focus on Sierra Leone that has taken a simultaneous look at inflation, exchange rate and economic growth. While a few have analyzed the relationship between exchange rate and inflation by looking at exchange rate pass-through to domestic prices, others have rather chosen to examine the relationship between exchange rate and trade balance. Thus, studies on the Sierra Leone economy are limited in scope and coverage. For instance, the studies on inflation dynamics in the Sierra Leone, 
International Journal of Social Science and Economic Research

ISSN: 2455-8834

Volume:06, Issue:02 "February 2021"

however, did not consider interrelationships between output, inflation, exchange rate and money supply.

\section{METHODOLOGICAL APPROACH}

The data was analysed using VECM technique. Our concern was to investigate the impact of exchange rate fluctuations and money supply on the general price level. We used VECM to do our analysis because it is the surest approach to analyse macroeconomic variables like exchange rate, money supply and price. We use price level (inflation) as our response variable whiles money supply, real output, expected rate of inflation, exchange rate, foreign prices are used as explanatory variable.

As part of the methodology, involved testing for unit root and cointegration, determination of correlation coefficient. Granger causality Test, which shows measures of inflation, can be predicted by performance in the real sector and the Vector Error Correction Mechanism (VECM) model which involves the use of Impulse Response Function and Variance Decomposition Function.

Diagnostic tests were carried out in order to test whether the residuals are Identically and Independently Normally distributed with zero mean and constant variance.

Here test for autocorrelation, heteroscedasticity, autoregressive conditional heteroscedasticity and normality were carried out under the diagnostic tests.

Though the sample size and the explanatory variables included in this study can be regarded as representative, adding variables like import prices indices in the price equation and using a larger sample than the one considered in this study may provide more reliable results regarding the behaviour of exchange rate, money and price in the Sierra Leone economy.

\subsection{GRANGER CAUSALITY TEST EQUATIONS}

To test the hypothesis that prices of goods and services are driven by movements in the exchange rate or that money supply drives inflation, the tripartite granger causality test was conducted. This is a test on the first difference of the variable its other variables. With an appreciable lagged length the test for causality will be conducted via the f-test. The equations for the granger causality test are as follows.

$$
\begin{aligned}
& \Delta \mathrm{Pt}=\mathrm{a}_{\mathrm{o}}+\sum \mathrm{ai} \Delta \mathrm{P}_{\mathrm{t}-1}+\ldots \sum \mathrm{bi} \Delta \mathrm{EXR}_{\mathrm{t}-1}+\mathrm{C} 1 \mathrm{~T}+\varepsilon_{1 \mathrm{t}} \\
& \mathrm{i}=1 \quad \mathrm{t}=1 \\
& \mathrm{EXR}_{\mathrm{t}}=\mathrm{d}_{\mathrm{o}}+\sum \mathrm{d} \Delta \mathrm{EXR}_{\mathrm{t}-1}+\ldots . . \sum \mathrm{Mi} \Delta \mathrm{P}_{\mathrm{t}-1}+\mathrm{C}_{2} \mathrm{~T}+{ }^{\varepsilon_{2 \mathrm{t}}} \\
& \mathrm{i}=1 \quad \mathrm{i}=1
\end{aligned}
$$




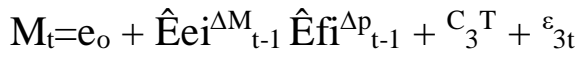

$$
\begin{aligned}
& \mathrm{C}=1 \quad \mathrm{C}=1 \\
& \Delta \mathrm{p}_{\mathrm{t}}=\alpha_{\mathrm{o}}+\hat{\mathrm{E}} \alpha \mathrm{i}^{\Delta \mathrm{p}} \mathrm{t}-1 \hat{\mathrm{E}}^{\mathrm{B}} \mathrm{i}^{\Delta \mathrm{M}} \mathrm{t}_{\mathrm{t}-1}+{ }^{\mathrm{C}}{ }_{4}^{\mathrm{T}}+^{\varepsilon}{ }_{4 \mathrm{t}} \\
& \mathrm{C}=1 \quad \mathrm{C}=1 \\
& \Delta \mathrm{EXR}_{\mathrm{t}}=\lambda_{\mathrm{o}}+\mathrm{i}^{\Delta \mathrm{EXR}}{ }_{\mathrm{t}-1} \hat{\mathrm{E}}^{\delta} \mathrm{i}^{\Delta \mathrm{M}} \mathrm{t}-1+{ }_{5}^{\mathrm{C}}{ }^{\mathrm{T}}+{ }^{\varepsilon}{ }_{5 \mathrm{t}} \\
& \mathrm{C}=1 \quad \mathrm{C}=1
\end{aligned}
$$

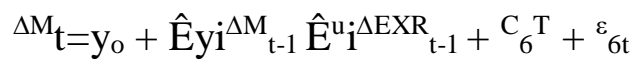

$$
\begin{aligned}
& \mathrm{C}=1 \quad \mathrm{C}=1
\end{aligned}
$$

Where ${ }^{\Delta}=$ the first deference operator,

$\mathrm{Pt}=$ the price level in period $\mathrm{t}$

$\Delta \mathrm{EXR}_{\mathrm{t}}=$ exchange rate in period $\mathrm{t}$

$\mathrm{M}_{\mathrm{t}}=$ money supply in period $\mathrm{t}$

$\mathrm{T}=$ time trend and

Where $\varepsilon_{1 \mathrm{t}}$ to $\varepsilon_{6 \mathrm{t}}$ are mutually exclusive uncorrelated white noise residuals.

The test for causality was done by obtaining the F-statistic for the each of the above equations. The null hypothesis is that there is no granger causality between the variables and the alternative hypothesis is that there exists a line of causation between the variables (money supply, exchange rate and prices). The null hypothesis is rejected if the calculated F-statistic is greater than the critical F-statistic at a given level of significance. Otherwise it is accepted.

\subsection{DATA SOURCES}

Secondary data are drawn from various sources for example; international financial statistics year books, Bank of Sierra Leone Bulletin (various issues), Statistics Sierra Leone, Economic Journals and Research Papers. Data on prices, base money, and Central Banks claims on Commercial Banks and Private Sector, Foreign Reserves, Exchange Rate, Gross Domestic Product and Money Supply (M2, broadly defined) were obtained from the appropriate sources mentioned above. The exchange rate is represented as the Leone against the dollar (Le per US\$1). The dollar is used because of the increase "dollarization" of the Sierra Leone economy.

\subsection{THEORETICAL FRAMEWORK}

The traditional monetarist's approach to the study of inflation stress the importance of the link between money supply and inflation; furthermore, it stressed that aggregate demand lead to 
increases in the price level, depending on demand shifts and the level of economic activity or unemployment. In econometric specification, we specify

$\mathrm{P}=\mathrm{f}(\mathrm{M}, \mathrm{S}, \mathrm{U})$

Where

$\mathrm{P}=$ Price Fluctuations

M= Money supply

$\mathrm{S}=$ Demand shifts

$\mathrm{U}=$ Unemployment.

The structuralist on the other hand, emphasize the role played by deficit financing or government expenditure, export earnings variations, import prices, demand shifts, agricultural bottlenecks and availability of foreign reserves. A close look at these factors reveals that the export earnings variation could be an explanatory of availability of foreign reserves. The latter is a good proxy for ability to import. Deficit financing is an important explanatory of the growth ofmoney supply.

Thus, the structuralists are inadvertently emphasizing money supply when they emphasize deficit financing. Import prices stands on its own as it explains the contribution of imported inflation. Demand shifts in the structuralists school do not differ from that of the monetarist school. The level of economic activity is already subsumed in the structuralists' theory since their theory pertains to developing economies where full employment is yet to be attained. One could therefore econometrically specify the structuralist theory of inflation as

$P=f\left(D F, E x r, P_{m}, S, A, R, U\right)$

Where

$\mathrm{DF}=$ Deficit Finance

Exr $=$ Exchange Rate

$\mathrm{P}_{\mathrm{m}}=$ Import Prices

$\mathrm{S}=$ Demand Shifts

A= Agricultural Bottlenecks 


\section{International Journal of Social Science and Economic Research}

ISSN: $2455-8834$

Volume:06, Issue:02 "February 2021"

$\mathrm{R}=$ Foreign Reserves

$\mathrm{U}=$ Level of Economic Activity

By removing DF and substituting M (Money supply), we have:

$P=f\left(M, E x r, P_{m}, A, S, R, U\right)$

The main structuralist point is that inflation can result from a number of special problems and not just from excessive money growth. Their search for explanations of inflation usually centres around "structural" problems such as supply bottlenecks or high dependency on imported intermediate goods. Inflation could also arise from the cost side. Costs could change through a supply shock, an increase in local earning power arising from a boom in export earnings, (in this case iron ore), or devaluation. Any of these could result in a push for higher nominal wages, which drive up production costs and increases final goods prices.

A synthesis of the Monetarists and the Structuralist specification would give us the latter specification since $\mathrm{M}, \mathrm{S}$, and $\mathrm{U}$ are common to both, and $\mathrm{R}, \mathrm{Pm}$ and $\mathrm{A}$ are peculiar to the structuralists. Our model for identifying the factors responsible for price increases in Sierra Leone in the period under review is an adaptation of thislatter specification:

$\mathrm{P}=\mathrm{f}\left(\mathrm{M}, \mathrm{Exr}, \mathrm{P}_{\mathrm{m}}, \mathrm{A}, \mathrm{S}, \mathrm{U}, \mathrm{R}\right)$

In our model, $\mathrm{M}$ measures money supply, defined as currency outside banks plus private sector demand deposits in the banking system. Pm is replaced by Pf, which represents foreign prices; A, for agricultural bottleneck which could be measured by food prices. But as food price is known to be the dominant component of the consumer price index in Sierra Leone, there will be a clear case of collinearity between it and the consumer price index. Therefore, A isremoved. $S$ for demand shift and R for the ability to import are yet to be acceptably specified. As such, they cannot be used in the model. Unemployment represented by $U$ and measuring only the unemployment of labour does not appear an adequate specification of the level of economic activity as it leaves out the unemployment of other factors of production. A better specification of the level of economic activity could be the level of real output. This datum represented by Y, measures how much all the factors of production in an economy are producing at a given time and therefore a good indicator of the level of economic activity. Also included in the model is expected rate of inflation $\left(\mathrm{P}_{\mathrm{t}-1}\right)$. Thus, the model becomes

$P=f\left(M, E x r, P f, Y, P_{t-1}\right)+U$;

$\mathrm{f}(\mathrm{M})>0, \mathrm{f}($ Exr $)>0, \mathrm{f}\left(\mathrm{P}_{\mathrm{f}}\right)>0, \mathrm{f}(\mathrm{Y})<0, \mathrm{f}\left(\mathrm{P}_{\mathrm{t}-1}\right)>0$ 


\section{International Journal of Social Science and Economic Research}

ISSN: $2455-8834$

Volume:06, Issue:02 "February 2021"

Where $\mathrm{U}$ is the error term.

The general price level can be expressed as a weighted average of the price of tradable goods (PT) and non-tradable goods (PN):

$\log \mathrm{P}=\beta(\log \mathrm{PN})+(1-\beta)(\log \mathrm{PT})$

Where $0<\beta<1$.

Where theory predicts that an increase in money supply, expected inflation, the exchange rate and foreign prices will drive prices up, while an increase in real output will lead to a decline in the inflation rate. Adding the effect of lagged prices to the equation can capture the effect of sluggish adjustment due to rigidities and inertia. This is in line with the definition employed in a study by Olopoenia (1986). The inflation equation considers the monetarists variables in addition to exchange rate. Thus, inflation is hypothesized to depend on growth in money supply, real output (measured by real GDP), expected rate of inflation, exchange rate changes and foreign prices.

\subsection{TIME SERIES PROPERTIES OF THE DATA}

Table 3.1 presents the estimates of the unit roots test for the stationarity of the variables at their levels and first difference. As a priori expected all the variables are non-stationary at level however, stationarity is induced after the first difference. Since the series are integrated of order one or I(1) that is, the first differences were stationary, the presence of significant cointegration relationships among the variables could be determined. Thus, the unit roots test further requires that the variables must cointegrate at the same order. This is confirmed by conducting cointegration test among the variables used in the model. The multivariate cointegration test established whether there was at least one linear long run relationship among the variables of interest found to be integrated of order one. The Johansen Maximum Likelihood procedure was applied, the estimates are as presented in table 3.2 below.

The price of tradable goods is determined in the world market and depends on foreign price (Pf) and on the exchange rate (e). In domestic currency terms, PT can be depicted by the following expression:

$\log \mathrm{PT}=\log \mathrm{e}+\mathrm{Pf}$

As can be seen from (7), both an increase in the exchange rate and a rise in foreign prices lead to an increase in domestic prices. The price of non-tradable goods is assumed to be determined in the domestic money market, where it is assumed that the demand for non-tradable goods moves in line with the overall demand in the economy. Accordingly, the price of nontradable goods is 
determined by the money market equilibrium condition, where real money supply (MS/P) equals real money demand $\left(M_{d}\right)$

$\log \mathrm{PN}=\beta\left(\log \mathrm{M}_{\mathrm{s}}-\log \mathrm{M}_{\mathrm{d}}\right)$

Where $\beta$ is a scale factor illustrating the relationship between economy-wide demand and demand for non-tradable goods. It is assumed that the demand for real balances is a function of real output $(y)$ and inflationary expectations $(\beta e)$. Due to relatively underdeveloped financial markets in Sierra Leone, it is assumed that the relevant substitution is between goods and money and not among different financial markets. Consequently, the opportunity cost of substitution between goods and money is the expected inflation rate.

$M_{d}=f(Y, \beta e)$

The expected rate of inflation is assumed to be determined by inflation in the previous period:

$\beta \mathrm{e}=\beta \log \mathrm{P}_{\mathrm{t}-1}$

The theory predicts that an increase in real income will lead to an increase in money demand, while an increase in expected inflation will lead to a decrease in money demand. Substituting and rearranging, we obtain the following estimable equation:

$\log P t=\beta_{0}+\beta_{1} \log M t+\beta_{2} \log Y t+\beta_{3} \log P_{t-1}+\beta_{4} \operatorname{loget}+\beta_{5} \log P_{f}+\varepsilon t$

On a priori grounds, the parameters are expected to have the following signs

$\beta_{1}>0, \beta_{2}<0, \beta_{3}>0, \beta_{4}>0, \beta_{5}>0$

$\beta_{0}=$ constant

$\mathrm{M}_{\mathrm{t}}=$ growth in money supply

$\mathrm{Y}_{\mathrm{t}}=$ growth in real output

$\mathrm{P}_{\mathrm{t}-1}=$ expected rate of inflation

et $=$ exchange rate

$\mathrm{P}_{\mathrm{f}}=$ foreign prices

$\varepsilon \mathrm{t}=$ error term.

From the model $\left(\beta_{1}>0\right)$ is expected to be positive. This is because an increase in the money supply is believed to increase the price level in general. 


\section{International Journal of Social Science and Economic Research}

ISSN: $2455-8834$

Volume:06, Issue:02 "February 2021"

$\beta_{2}<0$ means that the parameter $\beta_{2}$ is expected to be negative because an increase in output is believed to reduce the price level.

$\beta_{4}>0$ this implies that exchange in foreign currency terms and prices are positively related. That is, an increase in the value of foreign currencies (fall in value of domestic currency) will lead to an increase in the price of imports. The inelastic nature of imports in Sierra Leone will lead to an increase in prices hence price inflation.

If $\beta_{3}>0$, the expected inflation and the actual price inflation are directly related meaning that if people expected a future rise in prices, their demand for goods and services will be in excess of the quantity supplied for fear of being affected by the future increases in prices. This will lead to an increase in the general price level. Likewise, an expectation of future fall in prices reduces prices generally.

$\beta_{5}>0$, also implies that the relationship between the world price and domestic price are directly related, particularly for a country like Sierra Leone that is highly import dependent. Increases in the world are directly translated in the domestic economy in the form of increases in domestic prices generally

Table 3.1 ADF statistics for Testing Unit Roots in the Variables

\begin{tabular}{|l|c|r|c|}
\hline Variables* & Series & Levels & First Differences \\
\hline Broad Money Supply & LM2 & -0.5725 & -4.1978 \\
\hline Narrow Money Supply & LM1 & -0.9287 & -5.6918 \\
\hline Nominal Exchange rate & LNEER & -0.9054 & -7.3969 \\
\hline Real Exchange Rate & LREER & -0.9008 & -7.9243 \\
\hline Gross Domestic Output & LGDP & -0.6129 & -4.7089 \\
\hline US Wholesale price & LCPUS & -0.1907 & -4.6574 \\
\hline Inflation rate & LCPI & -1.3069 & -6.5934 \\
\hline Critical values & $1 \%$ & -3.5281 & -3.5267 \\
\hline & $5 \%$ & -2.9042 & -2.9035 \\
\hline
\end{tabular}

* All the variables are expressed in log forms.

The result of the cointegration test in table 3.2 confirms that there is more than one cointegration relationships among the variables included in the model. Specifically, the result of the cointegration test suggests that both money supply and exchange rate, irrespective of the ways they are defined, have equilibrium conditions with inflation, which kept them in proportion to each other in the long run. This evidence of cointegration among the variables rules out spurious correlations and implied that at least one direction of influence could be established among the variables. Both nominal exchange rate (NEER) and narrow money supply (M1) were also used 
International Journal of Social Science and Economic Research

ISSN: 2455-8834

Volume:06, Issue:02 "February 2021"

to represent exchange rate and money supply in the cointegration tests. The results are similar with the result reported in table 3.2 hence are not reported to conserve space as it will amount to unnecessary duplication but are available on request.

Table 3.2 Cointegration Tests

\begin{tabular}{|lcccl|}
\hline $\begin{array}{l}\text { Likelihood } \\
\text { Eigen value }\end{array}$ & $\begin{array}{c}\text { 5 Percent } \\
\text { Ratio }\end{array}$ & $\begin{array}{c}\text { 1 Percent } \\
\text { Critical Value }\end{array}$ & $\begin{array}{c}\text { Hypothesized } \\
\text { Critical Value }\end{array}$ & No. of CE(s) \\
\hline 0.765171 & 316.0358 & 94.15 & 103.18 & None ** \\
0.591042 & 214.6130 & 68.52 & 76.07 & At most $1^{* *}$ \\
0.544134 & 152.0230 & 47.21 & 54.46 & At most $2 * *$ \\
0.511709 & 97.03408 & 29.68 & 35.65 & At most $3 * *$ \\
0.311625 & 46.85499 & 15.41 & 20.04 & At most $4 * *$ \\
0.256165 & 20.71548 & 3.76 & 6.65 & At most 5** \\
\hline Sources: Data Analysis \\
Series: GCPI GRGDP GREER GM2 GCPS GLR \\
Lags interval: No lags
\end{tabular}

NOTE: $*(* *)$ denotes rejection of the hypothesis at $5 \%(1 \%)$ significance level

L.R. test indicates 6 cointegrating equation(s) at $5 \%$ significance level

\subsubsection{GRANGER CAUSALITY}

This test determines which variable(s) cause or causes the other. The first step in a granger test equation is assigning the appropriate lag length to the variables. From this, the DW statistic is calculated for all the variables. The values for this parameter in table 3.3 are shown below,

Trivariate Granger Causality Test on Prices, Exchange Rate and Money Supply in Sierra Leone (1986-2012)

Table 3.3

\begin{tabular}{|l|l|l|l|l|}
\hline Direction & \multicolumn{1}{|c|}{ F-statistic } & \multicolumn{1}{c|}{ Sign } & \multicolumn{1}{c|}{ DW-statistic } & \multicolumn{1}{c|}{ Decision } \\
\hline Price to money & $\mathrm{F}(7,18) 10,17$ & Positive & 0.74 & Reject Ho \\
Money to prices & $\mathrm{F}(7,18) 13,64$ & Positive & 0.84 & Reject Ho \\
\hline Prices to exchange & $\mathrm{F}(7,18) 10,78$ & Positive & 0.63 & Reject Ho \\
Exchange rate to money & $\mathrm{F}(7,18) 12,09$ & Positive & 0.64 & Reject Ho \\
\hline Money to exchange & $\mathrm{F}(7,18) 10,37$ & Positive & 0.56 & Reject Ho \\
Exchange rate money & $\mathrm{F}(7,18) 9,17$ & Positive & 0.58 & Reject Ho \\
\hline
\end{tabular}




\section{International Journal of Social Science and Economic Research}

ISSN: $2455-8834$

Volume:06, Issue:02 "February 2021"

Note:

The critical F-Statistic with degrees of freedom $\mathrm{F}(7,18)$ is 2.58 .

The deciding criteria is that if the F-value calculated is greater than the critical $\mathrm{F}$ value at $5 \%$ significant level the null hypothesis of no Granger causality is rejected, otherwise the alternative hypothesis of Granger causality among the variables is accepted. According to the results there is a two-way causality between money and prices. This means that monetary growth causes prices and prices causes monetary. In other words there is a feedback effect between money and prices. This supports the cardinal premise of this study that exchange rate movement and growth in money supply contributed significantly to the increases in the general price level. The feedback probably occurs because government finances its deficit through money creation. The inflation arising from deficit financing induces the government to prompt the monetary authorities to create more money and creating money expands the money supply. This later lead to an increase in aggregate demand which in turn leads to an inflationary spiral in the economy. This feedback effect supports the findings of Aghevli and Khan (1978) that monetary expansion causes inflation and inflation causes monetary expansion. This is in contrast to Killick and Mwega (1989) and (1991) who concluded that is unidirectional causality between money and prices and it runs from money to price.

Similar feedback effect exists between money supply and exchange rate. Exchange rate causes money and money causes exchange rate. This result is different from the study undertaken by Cannetti and Greene (1991).

They concluded that there is no significant causal relationship between money, price and exchange rates in Nigeria and Zambia. In their study on monetary policy in Kenya Killick and Mwega (1989) concluded that money supply causes the exchange rate with no feedback effects.

\subsubsection{DIAGNOSTIC TESTS}

In order to determine the robustness of the vector error correction model diagnostic and stability tests were carried out. These included test for normality of the regression residuals, test for serial correlation, and test for heteroscedasticity, test for auto regressive conditional heteroscedasticity, functional form misspecification and test for stability. Table 3.4 shows the results of the diagnostic tests.

Table 3.4 shows that the model is free from serial correlation, heteroscedasticity and auto regressive conditional heteroscedasticity (ARCH effect). 
International Journal of Social Science and Economic Research

ISSN: 2455-8834

Volume:06, Issue:02 "February 2021"

Table 3.4 SOME DIAGNOSTIC TESTS FROM ERROR CORRECTION MODEL

\begin{tabular}{|l|l|l|l|l|}
\hline \multicolumn{1}{|c|}{ Test } & \multicolumn{1}{|c|}{$\begin{array}{c}\text { Test } \\
\text { Statistics }\end{array}$} & \multicolumn{1}{c|}{ Test Type } & \multicolumn{1}{c|}{ Implication } \\
\hline F-Statistic & $\mathrm{R}^{2}$ & & \\
\hline Serial Correlation & $\begin{array}{l}0.3066 \\
(0.7390)\end{array}$ & $\begin{array}{l}0.9492 \\
(0.6221)\end{array}$ & Brasch-Godfrey LM & No Serial Correlation \\
\hline Heteroscedasticity & $\begin{array}{l}1.5645 \\
(0.1975)\end{array}$ & $\begin{array}{l}24.1809 \\
(0.2346)\end{array}$ & $\begin{array}{l}\text { White } \\
\text { Heteroscedasticity } \\
\text { with no cross term }\end{array}$ & No heteroscedasticity \\
\hline $\begin{array}{l}\text { Auto Regressive } \\
\text { Conditional }\end{array}$ & $\begin{array}{l}1.0122 \\
(0.3219)\end{array}$ & $\begin{array}{l}1.0425 \\
(0.3072)\end{array}$ & LM Test & $\begin{array}{l}\text { No auto-regressive } \\
\text { conditional } \\
\text { heteroscedasticity }\end{array}$ \\
$\begin{array}{l}\text { Heteroscedasticity } \\
\text { (ARCH) }\end{array}$ & 1.7138 & $\begin{array}{l}\text { Jarque- Bera } \\
\text { Residual } \\
\text { Termality }\end{array}$ & $(0.4245)$ & $\begin{array}{l}\text { The residuals } \\
\text { Are normal }\end{array}$ \\
\hline $\begin{array}{l}\text { Misspecification } \\
\text { Test }\end{array}$ & $\begin{array}{l}0.6009 \\
(0.4461)\end{array}$ & $\begin{array}{l}\text { Log } \\
\text { Likelihood } \\
\text { Ratio 0.9027 } \\
(0.342)\end{array}$ & Ramsey RESET Test & $\begin{array}{l}\text { Model is correctly } \\
\text { specified }\end{array}$ \\
\hline
\end{tabular}

\section{EMPIRICAL RESULTS AND ANALYSIS}

We explore the cointegration and Vector Error Correction Mechanism (VECM) techniques. This is due to the fact that the variables of interest are simultaneously related, hence the need to treat each variable symmetrically and allow feedback among them. Second, VECM analysis is superior to a single equation approach for capturing the long-run dynamics of variables (Enders, 1995; Feasel, Kim and Smith, 2001). This technique enables us to verify the stationarity as well as the order of integration of the variables used in the model. The method also enables us to establish the long-run relationship between exchange rate, money supply and inflation.

Data were sourced from the International Financial Statistics (IFS) yearbook and Central Bank of Sierra Leone's (BSL)) Economic and Financial Review of Various years. The data covers the period of estimation, that is, 1986 to 2012. Quarterly data for this period was used (1986: 01 to 2012: 04) rather than annual data, this is in order to have enough degrees of freedom for estimation and also the desire to minimize any problems with temporal aggregation (see Christiano and Eichenbaum, 1992). 
International Journal of Social Science and Economic Research

ISSN: 2455-8834

Volume:06, Issue:02 "February 2021"

\subsection{ANALYSIS OF LONG RUN EFFECTS OF MONEY SUPPLY ANDEXCHANGE RATE FLUCTUATIONS ON INFLATION}

To examine the long-run effect of money supply and exchange rate on inflation, Vector Error Correction Mechanism (VECM) which incorporates both the long run and short run effect simultaneously is estimated. The beauty of VECM is that once variables are non-stationary but cointegrated, the estimates from VECM are more efficient than either the Ordinary least Square or orthodox VAR estimates. The VECM also saves one from the agony of endogeneity problem and the inherent spurious inferences associated with OLS estimates.

\section{Table 4.1: The Multivariate Causality (VECM) Results (Model I)}

Co integrating Eq: CointEq1

\begin{tabular}{lc}
\hline LCPI (-1) & 1.000000 \\
LRGDP (-1) & 1.090160 \\
& $(1.99525)$ \\
LM2 (-1) & -1.164565 \\
& $(-2.13838)$ \\
LREER (-1) & -0.553013 \\
& $(-3.38066)$ \\
LCPUS (-1) & 0.173883 \\
& $(0.35484)$ \\
C & -2.993602 \\
\hline
\end{tabular}

\begin{tabular}{|c|c|c|c|c|c|c|c|}
\hline Error Correction: & & (LCPI) & $\mathrm{D}(\mathrm{LRGDP})$ & \multicolumn{2}{|c|}{$\mathrm{D}(\mathrm{LM} 2)$} & D(LREER) & $\mathrm{D}(\mathrm{LCPUS})$ \\
\hline CointEq1 & $\begin{array}{l}-0.0 \\
(-3 .\end{array}$ & $\begin{array}{l}020961 \\
63633)\end{array}$ & $\begin{array}{l}-0.027923 \\
(-1.35374)\end{array}$ & \multicolumn{2}{|c|}{$\begin{array}{l}0.026359 \\
(1.90384)\end{array}$} & $\begin{array}{l}1.675878 \\
(5.46949)\end{array}$ & $\begin{array}{c}0.012037 \\
(0.43881)\end{array}$ \\
\hline $\mathrm{D}(\mathrm{LCPI}(-1))$ & & $\begin{array}{l}470172 \\
59783)\end{array}$ & $\begin{array}{l}-0.112793 \\
(-0.68500)\end{array}$ & \multicolumn{2}{|c|}{$\begin{array}{c}-0.11932 \\
(-1.07956)\end{array}$} & $\begin{array}{l}-1.268182 \\
(-0.51847)\end{array}$ & $\begin{array}{r}0.143677 \\
(0.65611)\end{array}$ \\
\hline D(LRGDP(-1)) & $\begin{array}{l}-0.0 \\
(-0 .\end{array}$ & $\begin{array}{l}014942 \\
19643)\end{array}$ & $\begin{array}{l}0.370573 \\
(3.02538)\end{array}$ & \multicolumn{2}{|c|}{$\begin{array}{l}0.053928 \\
(0.65591)\end{array}$} & $\begin{array}{l}-1.145135 \\
(-0.62936)\end{array}$ & $\begin{array}{l}-0.114020 \\
(-0.69996)\end{array}$ \\
\hline $\mathrm{D}(\mathrm{LM} 2(-1))$ & & $\begin{array}{l}313672 \\
72678)\end{array}$ & $\begin{array}{l}-0.116520 \\
(-0.62905)\end{array}$ & \multicolumn{2}{|c|}{$\begin{array}{l}-0.042118 \\
(-0.33875)\end{array}$} & $\begin{array}{l}-1.140130 \\
(-0.41435)\end{array}$ & $\begin{array}{l}0.119246 \\
(0.48408)\end{array}$ \\
\hline D(LREER(-1)) & $\begin{array}{l}-0.1 \\
(-0.8\end{array}$ & $\begin{array}{l}004406 \\
86329)\end{array}$ & $\begin{array}{l}-0.009672 \\
(-1.17685)\end{array}$ & \multicolumn{2}{|c|}{$\begin{array}{l}0.011916 \\
(2.16008)\end{array}$} & $\begin{array}{l}-0.043320 \\
(-0.35484)\end{array}$ & $\begin{array}{l}0.003255 \\
(0.29784)\end{array}$ \\
\hline $\mathrm{D}($ LCPUS(-1)) & & $\begin{array}{l}44695 \\
72751)\end{array}$ & $\begin{array}{l}-0.048735 \\
(-0.49265)\end{array}$ & \multicolumn{2}{|c|}{$\begin{array}{l}0.037845 \\
(0.56994)\end{array}$} & $\begin{array}{l}0.095202 \\
(0.06478)\end{array}$ & $\begin{array}{c}-0.092845 \\
(-0.70573)\end{array}$ \\
\hline $\mathrm{C}$ & & $\begin{array}{l}07153 \\
55924)\end{array}$ & $\begin{array}{l}0.022085 \\
(1.26403)\end{array}$ & \multicolumn{2}{|c|}{$\begin{array}{l}0.070359 \\
(5.99943)\end{array}$} & $\begin{array}{c}0.129546 \\
(0.49914)\end{array}$ & $\begin{array}{l}0.057403 \\
(2.47051)\end{array}$ \\
\hline Adj. R-squared & \multicolumn{2}{|c|}{$0.751663 \quad 0.101235$} & 0.022056 & \multicolumn{3}{|c|}{-0.066416} & \\
\hline Akaike AIC & \multicolumn{2}{|c|}{$\begin{array}{ll}-3.087535 & -2.134767\end{array}$} & -2.932045 & 3.261877 & \multicolumn{2}{|c|}{-1.564586} & \\
\hline F-statistic & 5.967686 & 2.295333 & 1.259363 & 10.11505 & \multicolumn{2}{|c|}{0.283784} & \\
\hline Log likelihood & 115.0637 & 81.71686 & 109.6216 & -107.1657 & \multicolumn{2}{|c|}{61.76050} & \\
\hline R-squared & 0.362388 & 0.179388 & 0.107094 & 0.490663 & \multicolumn{2}{|c|}{0.026316} & \\
\hline S.D. dependent & 0.058983 & 0.083720 & 0.053873 & 1.578567 & \multicolumn{2}{|c|}{0.102212} & \\
\hline S.E. equation & 0.049290 & 0.079369 & 0.053275 & 1.179016 & \multicolumn{2}{|c|}{0.105552} & \\
\hline Schwarz SC & \multicolumn{2}{|c|}{$-2.862685-1.909918$} & -2.707196 & 3.486726 & \multicolumn{2}{|c|}{-1.339736} & \\
\hline
\end{tabular}


International Journal of Social Science and Economic Research

ISSN: 2455-8834

Volume:06, Issue:02 "February 2021"

Determinant Covariance

Log Likelihood

Akaike Information Criteria

Schwarz Criteria

\author{
Residual 3.06E-10 \\ 270.1841 \\ $-6.576689$ \\ $-5.291834$
}

The VECM has two parts. In the first part, the estimates of the long run effects are presented while the second part contains the estimates of the short run dynamic interaction among the variables. The Second part is also linked with first part (long run relation) by the ECM. The ECM is a measure of the speed of adjustment of the short run relation to unexpected shocks. It is measured as the effects of residual from the long run model. This long run feedback effect is indicated by significant ECM terms while the short run causality is measured by the significant coefficient on the individual variables. The cointegration test conducted earlier is mainly to establish whether this ECM term (derived from the residual of long run regression) is stationary at level or not and to determine how many of such relationships exist. As confirmed thereof, there is significant long run relationship among the variables. However, the fact that there is presence of long run relationship among the variables included in the model does not automatically imply that all the variables in the model have significant effects on the dependent variable.

Therefore, to determine which variable actually elicit the observed long run relationship, there is the need to estimate the long run model and then analyse the estimates. As estimates in first part of the Table 4.1 show, all the variables except foreign price, have negative and significant effects on the fluctuation of price level in longrun. While the negative effects of real GDP and real exchange rate can easily be justified, the negative effects of money supply raises further issues about the usual theoretical linkage between money supply and price. According to traditional macroeconomic theory, money should have positive and significant effect on price level in the long run. The possible justification for the negative effect of money supply on price level is that inflation may not be due to aggregate demand pressure but rather due to hiccups in the supply chain of goods both from the domestic and foreign supply outlets. In other words the fluctuation in the price level is more of aggregate supply induced rather than aggregate demand.

Also, given the higher coefficient of exchange rate, it seems that exchange rate is more relevant in price determination in Sierra Leone than monetary expansion and real output production. This corroborates many other studies (see Kamin 1996; Brouwer and Ericsson 1998; Durevall 1998 and Harberger 1963). Considering the short run effects of these variables on inflation; only money supply is the significant variable which is in line with apriori theoretical expectation. It confirms the overwhelming influence of monetary expansion both from fiscal impulses and financial intermediation on the liquidity level in the country. Increases in the liquidity volume in the economy raises the real money balances of the people which induces aggregate demand. The 
International Journal of Social Science and Economic Research

ISSN: 2455-8834

Volume:06, Issue:02 "February 2021"

sluggishness of supply to respond to the short run and unexpected increase in demand put pressure on the price to rise and hence generates inflationary tendency in the short run. As the long run estimates shows, the aggregate supply would have increased and the effect of monetary expansion dies down while supply remains the only determinant of the price fluctuation. There have been several arguments on thepossible factor generating persistent increase in price level in Nigeria. While some studies (Akinlo, 2003; Ajisafe and Folorunso, 2002) argue that it is the excessive government spending that result in expansion in money supply, others (Masha, 2000; Ajayi and Awosika, 1980) argue that it is externally induced by the petrol dollar income. While these two positions may still be valid, there is some evidence that the major cause of price fluctuation in most developing countries is the exchange rate fluctuation. There are several reasons for this. In import dependent country like Sierra Leone, changes in exchange rate is directly reflected in the prices of the goods and services.

\subsection{ANALYSIS OF IMPULSE RESPONSE AND VARIANCE DECOMPOSITION}

There is suspicion about the statistical efficiency of the coefficient estimates from the VECM hence most often scholars are more comfortable with the impulse response and variance decomposition as a better way of analysing the contribution of policy variables to target variables in macroeconomic model. This approach is followed in this study to analyse the relative contribution of both money supply and exchange rate to fluctuation in price level. As in any standard VAR model analysis, the way the variables entered the model is extremely important for the interpretation of the results. Therefore, in this study, the policy variables were placed first then followed by the target variables. This is based on the economic intuition that the policy variables influence the target variables contemporaneously, while the target variables influence the policy variables through the system overtime. It may alternatively be said that the target variables are 'less' endogenous than the policy variables (Akinlo, 2003). The ordering used are: foreign price indices (CPUS), exchange rate (REER), money supply (M2), real GDP and domestic price indices (CPI). The Tables 4.2, 4.3, and Figure 1 depict the impulse response and variance decomposition of price changes due to innovations to exchange rate, money supply , real GDP and foreign price indices measured by US price indices of economic growth variables of the model using a horizon of ten quarters.

Table 4.2 Impulse Responses to One-S.D Innovations

\begin{tabular}{|c|c|c|c|c|c|}
\hline Period & LCPI & LRGDP & LM2 & LREER & LCPUS \\
\hline 1 & 0.044448 & -0.006173 & 0.011353 & 0.006629 & -0.000191 \\
\hline 2 & 0.064 & -0.011750 & 0.032147 & 0.014717 & 0.008856 \\
\hline 3 & 0.071706 & -0.014541 & 0.040288 & 0.021947 & 0.013698 \\
\hline 4 & 0.074544 & -0.015690 & 0.042793 & 0.020370 & 0.015711 \\
\hline
\end{tabular}


International Journal of Social Science and Economic Research

ISSN: 2455-8834

Volume:06, Issue:02 "February 2021"

\begin{tabular}{|c|c|c|c|c|c|}
\hline 5 & 0.075972 & -0.015894 & 0.044120 & 0.019586 & 0.016464 \\
\hline 6 & 0.076635 & -0.015854 & 0.044766 & 0.019334 & 0.016804 \\
\hline 7 & 0.076922 & -0.015801 & 0.045056 & 0.019270 & 0.016942 \\
\hline 8 & 0.077039 & -0.015769 & 0.045178 & 0.019261 & 0.016997 \\
\hline 9 & 0.077084 & -0.015754 & 0.045226 & 0.019263 & 0.017018 \\
\hline 10 & 0.077101 & -0.015748 & 0.045244 & 0.019266 & 0.017026 \\
\hline
\end{tabular}

The following conclusions emerge from the examination of the impulse response functions. From Table 4 and Figure 1 the dominance of expansionary impact of money supply shock on the inflation rate all through the ten-quarter horizon is established and confirms the results elicited by the VECM model above. Followed in effects is real exchange rate and foreign inflation. The least effect is from the real GDP. Moreover, the result of the impulse response also confirms the weakness of both exchange rate and real GDP to influence inflation in the short run. Indeed, while all the coefficients of money supply shocks have positive effects, real GDP has negative effects all throughout the ten periods. Exchange rate and foreign price also have positive effect on price level. This implies that a unit S.D shock to either money supply or exchange rate or both will result in higher inflation rate in Sierra Leone. Likewise, a reduction in monetary expansion and exchange rate will be an effective instrument in taming excessive price fluctuation in Sierra Leone.

Table 4.3 present the variance decomposition of the variables used in the model. The salient results from the variance decomposition are as follows: In general 'own shock' constituted the predominant source of variations for price variable in the model. Apart from own shock, the most dominant variable is money supply. All through the ten-period horizon, it maintained an average significant influence of about $20 \%$. The next most significant determinant of Inflation is real exchange rate which maintains an average of 5\% throughout the ten periods. Foreign price and real GDP trailed behind and both explained less that 5\% of the variation in price fluctuation in Sierra Leone.

Table 4.3 Variance Decomposition Results

\begin{tabular}{|c|c|c|c|c|c|c|}
\hline Period & S.E. & LCPI & LRGDP & LM2 & LREER & LCPUS \\
\hline 1 & $0 . \overline{046761}$ & 90.35127 & 1.742943 & 5.894207 & 2.009904 & 0.001676 \\
\hline 2 & 0.088331 & 78.50026 & 2.257897 & 14.89704 & 3.339078 & 1.005732 \\
\hline 3 & 0.124289 & 72.93254 & 2.509124 & 18.03122 & 4.804579 & 1.722546 \\
\hline 4 & 0.154090 & 70.85331 & 2.669205 & 19.44379 & 4.873385 & 2.160311 \\
\hline 5 & 0.179915 & 69.80359 & 2.738326 & 20.27616 & 4.759854 & 2.422064 \\
\hline 6 & 0.202864 & 69.17437 & 2.764600 & 20.81770 & 4.652118 & 2.591209 \\
\hline 7 & 0.223627 & 68.75753 & 2.774306 & 21.19090 & 4.570895 & 2.706374 \\
\hline
\end{tabular}


International Journal of Social Science and Economic Research

ISSN: 2455-8834

Volume:06, Issue:02 "February 2021"

\begin{tabular}{|c|c|c|c|c|c|c|}
\hline 8 & 0.242680 & 68.46239 & 2.777987 & 21.45968 & 4.511288 & 2.788660 \\
\hline 9 & 0.260365 & 68.24320 & 2.779527 & 21.66068 & 4.466657 & 2.849935 \\
\hline 10 & 0.276931 & 68.07435 & 2.780294 & 21.81595 & 4.432244 & 2.897171 \\
\hline
\end{tabular}

The general observation from the estimates so far is that inflation pressure in Sierra Leone has been much more occasioned by the expansionary monetary policy and exchange rate. Though in the long run real output has some influence on price level but such influence is less is in most cases dominated by the influence of money supply and real exchange rate. In terms of relative effect of money supply and exchange rate, money supply seems more influential than exchange rate in price determination in Sierra Leone. The approach need be tailored in line with the monetary objective of the government. Since the banks can on their own increase the liquidity of the economy through their money creation capacity, then banks must be involved in articulating and implementing monetary policy. The era where the monetary policy guidelines were just passed down to the financial operators should be a thing of the past. To properly and effectively curtail inflation in Sierra Leone, all stakeholders must be made to make input into monetary policy and be convinced about the sincerity of the government. The evidence from the studythat exchange rate does not significantly influence inflation may explain the current observation in which we have little or no influence on inflationary pressure in Sierra Leone.

\section{SUMMARY OF FINDINGS}

The estimation result shows that increase in money supply will lead to increase in inflation rate in short run but an insignificant effect in the long run. Therefore, it implies that monetary expansion has remained the main causal factor of the persistent increase in price level in Sierra Leone. There is controversy on whether inflation in developing countries like Sierra Leone could be explained from monetarist perspective in view of the enormous bottleneck in the supply chain in food and material resources flow in Sierra Leone. The excessive monetary expansion in Sierra Leone where endemic corruption and conspicuous spending is a general trait of the government makes the monetary argument more potent than the supply side argument where inflation is seemed to be caused by supply rigidity.

Therefore, to tame inflationary pressure in Sierra Leone, the excessive fiscal expansion has to be curtailed. The banks credit management approach need be tailored in line with the monetary objective of the government. Since the banks can on their own increase the liquidity of the economy through their money creation capacity, then banks must be involved in articulating and implementing monetary policy. The era where the monetary policy guidelines were just passed down to the financial operators should be a thing of the past. 


\section{International Journal of Social Science and Economic Research}

ISSN: $2455-8834$

Volume:06, Issue:02 "February 2021"

To properly and effectively curtail inflation in Sierra Leone, all stakeholders must be made to make input into monetary policy and be convinced about the sincerity of the government. The evidence from the study exchange rate does not significantly influence inflation may explain the current observation in Sierra Leone where exchange rate is appreciating but both imported and domestically produced goods continue to experience rise in prices. It means that exchange rate fluctuation has little or no influence on that inflationary pressure in Sierra Leone. Foreign price seems not to be a crucial factor in inflation dynamism while real output growth seems to play more or less a little role in price fluctuation in Sierra Leone. One other important implication arising from the result is that real variable that is, real output has an inverse effect on inflation; thus, implying that the supply side argument also holds. That is, increasing the supply of goods and services will reduce the pressure on price level. This means that increase in real output can also be used to stop excessive inflationary pressure. This involves determining the univariate time series behaviour of the variables or testing the variables for the presence of unit roots to determine whether there is a long run relationship among the variables, a common practice in mode in econometric research. These are tests against the null hypothesis that the variables have unit roots the test for unit roots on the variables is conducted with the help of the Dicky-fuller (DF) and Augmented Dicky Fuller (ADF) tests. After this, tests for co-integration between the dependent variables and the explanatory variables are performed. The test for co-integration 1 was carried out on the residual of the long nun static regression (co-integration regression).

\subsection{CONCLUSIONS AND POLICY RECOMMENDATIONS}

Inflation in Sierra Leone is positively related to money supply growth and real exchange rate depreciation, but negatively related to real GDP growth as observed from the coefficient estimates, impulse response functions and variance decomposition analyses. The result also revealed the existence of inflation inertia. Real exchange rate depreciation is explained by its own past values, money supply growth and inflation.

The model passes all the diagnostic tests conducted, implying the results are not only consistent, efficient and unbiased but also non-spurious. Inflation and real exchange rate depreciation do not impact real GDP growth in Sierra Leone. Real money supply growth has net dynamic effect implying that cumulative increases in broad money supply will cause real inflation to in the current period. Real GDP growth exerts positive inertia in Sierra Leone such that an increase in real GDP will lead to increase in the general price level. Generally, growth appears to be driven by its own past values, probably by traditional supply side factors, and not demand-side variables. In the VAR framework, the model has explanatory power of 86.9 percent. None of the underlying assumptions of the estimation technique is violated according to the diagnostic tests conducted. 


\section{International Journal of Social Science and Economic Research}

ISSN: $2455-8834$

Volume:06, Issue:02 "February 2021"

To achieve sustainable growth in the mist of low inflation (non-inflationary growth) in Sierra Leone the authorities should implement policies aimed at resolving supply-side challenges in a view to increasing domestic production and achieving sustainable economic growth. This can be achieved through continued increase in infrastructure, energy and power supply, among others.

In addition, the authorities are encouraged to maintain price stability, through the implementation of prudent monetary policy and maintaining exchange rate stability. The authorities should note that increasing money supply in the short run to enhance real GDP growth, may lead to dynamic inconsistency, causing long run inflation without increase in real GDP. In this regard, policies aimed at achieving low inflation are desirable.

Another policy implication arising from the study is that the authorities should provide a more favourable environment that would increase both traditional and non-traditional exports, increase domestic production of non-tradable and boost economic activities in the tourism sector. These activities might lead to increase in foreign exchange inflows and help stabilize the domestic currency. Stable domestic currency in turn attracts foreign investments. Large domestic production for export and potential for foreign investment caused by a stable domestic currency will increase the level of employment. This will provide a large revenue base for government through taxation.

The financing of huge budget deficits by the central bank through money creation is shown in this study to contribute to inflation in the economy. This arises because government cannot raise enough revenue to finance its expenditure. To reduce the effect for monetary growth on prices, government should improve its revenue collection to remove lags in the collection of revenue.

Further expenditure adjustment should be undertaken by government. Extra budget expenditure should be avoided except for very vital programme. Tight monetary and fiscal policies especially during periods of devaluations lower the rate of inflation by reducing excess demand for imports and foreign exchange in the economy.

Shortages of foreign currency in the official market fuels black market activities. Adopting a flexible exchange rate policy should be considered and undertaken by government. This will encourage inflow of foreign currency into the domestic economy. The central bank should intensify their monitoring of foreign exchange bureaus to enhance their effective functioning and management of foreign currency.

Increase in world price (external stock) has a negative effect on domestic prices. Policies to enhanced export values and expenditure costs must be pursued as such policy may help sustain domestic demand. Smuggling of exports (both minerals and agricultural sectors) should be 
International Journal of Social Science and Economic Research

ISSN: 2455-8834

Volume:06, Issue:02 "February 2021"

discouraged and foreign exchange surrender obligations be enforced effectively and indiscrimately. This will make foreign currency available and reduce shortages.

This research shows that prices and money supply drive exchange rate both with a reverse effect. Therefore, to improve the health of the economy monetary and exchange rate policies should be undertaken simultaneously or in combination so that they can supplement each other.

An independent central bank is recommended so that it can effectively control monetary and exchange rate policy to eliminate inflationary bias of discretionary policy. Price stability should be one of the bank's principal goals. The evidence shows that the more the independent the more likely the rate of inflation is said to be low, although critics hold a different view.

Considering devaluation, the government should allow the market forces to determine the exchange rate rather than official devaluations. Nonetheless, if the government is to pursue to a devaluation policy, it should ensure that the devaluation should be less than or equal to the difference between the official and parallel exchange rates, so that it will have mineral direct impact on prices.

\section{References}

Agenor Pierre-Richard, (1986), "Money, Exchange Rates and Inflation in Africa", A Vector Autoregression Analysis, unpublished Paper, International Monetary Fund.

Bijan B. Aghevli, Mohsin S. Khan and Peter J. Montiel (1991) "Exchange Rate Policy in Developing Countries”, Some Analytical Issues, Occasional Paper,International Monetary Fund.

R.AAjisafe and B.A. Folorunso (2002) "The relative Effectiveness of Fiscal and Monetary Policy in Macroeconomic Management in Nigeria", African Economic and Business Review.

A.E. Akinlo (2003) "The Determinants of Inflation in Nigeria", Indian Journal of Economics, LXXXVI(341).

M. Bleaney (2001) "Exchange Rate Regimes and Inflation Persistence", IMF Staff Papers, 47(3).

G. Brouwer and N.R. Ericsson (1998) "Modelling Inflation in Australia"Forthcoming, Journal of Business and Economic Statistics.

Guillermo A. Calvo, M. Reinhart Carmen and A. Végh Carlos (1994) "Targeting the Real Exchange Rate" Theory and Evidence, IMF Working Paper, 94/22. 
International Journal of Social Science and Economic Research

ISSN: 2455-8834

Volume:06, Issue:02 "February 2021"

Elias Canetti and Joshua Greene (2000) "Monetary Growth and Exchange Rate Depreciation as Causes of Inflation in African Countries" International Monetary Fund, Washington, D.C., World Bank Working Paper.

A. Chhibber, and al.(1989) "Inflation, Price Controls and Fiscal Adjustment in Zimbabwe" World Bank Working Papers, WPS 192, World Bank, Washington DC.

A. Chibber and N. Shafik (1990) "Exchange Reform, Parallel Markets and Inflation in Africa" The Case of Ghana, World Bank Working Paper, WPS 427, World Bank, Washington DC.

E. Christiano and M. Eichenbaum (1992), "Comments on Interpreting the Macroeconomic Time Series Facts: The Effects of Monetary Policy,European Economic Review, 36, 1001-1011.

D. Dick and S.N. Njuguna, (1998) “A Dynamic Model of Inflation for Kenya 1974-1996” Working Papers in Economics.

David A. Dickey and A. Fuller Wayne (1979), "Distribution of the Estimators for Autoregressive Time Series With a Root", Journal of the American Statistical Association, 427431.

Ibrahim A. Elbadawi (1990) "Inflationary Process, Stabilisation and the Role of Public Expenditure in Uganda", Washington, D.C., World Bank Working Paper.

DmytoHolod (2000) "The Relationship between Price Level, Money Supply and Exchange Rate in Ukraine", A thesis submitted to the National University of Kiev-Mohyla Academy.

S. Johansen (1988) "Statistical Analysis of Cointegration Vectors", Journal of Economic Dynamics and Control, 231-254.

Dornbusch, R (1988): "Exchange Rate and Inflation" The MIT Press, Cambridge, Massachusetts London, England.

Gujarati, D.N. (1991).“Basic Econometric International edition” PP. 620-624, 727-728.

Killic T. and F.M Mwega (1989) "Monetary policy in Kenya, 1967-88" ODI Working Paper No 39.

Keren, P.B and C. Pack, C (1980) "Exchange Rate, Domestic Prices and the Adjustment Prices" Occasional Paper No. 1, The Group of Thirty, New York.

Kallon, K (1992) “An Econometric Analysis of Inflation in Sierra Leone” Journal of African Economics Vol. 3, No. 2 PP 199-229, University of Northern Colorado. 
International Journal of Social Science and Economic Research

ISSN: 2455-8834

Volume:06, Issue:02 "February 2021"

Kamara, A (1996) "Output Growth, Money Supply and Inflation in a War-=torn Economy" Evidence from Sierra Leone. Unpublished M.Sc. thesis, Addis Ababa University, Ethiopia

Ndung'u, N. (1994) “A Monetarist model of inflation Kenya case" African Development Review, December. 